\section{SEEDS}

Surrey Energy Economics

Discussion paper Series
SURREY

ENERGY

ECONOMICS

Centre

\title{
Freeing the Nuclear Industry
}

\author{
Colin Robinson
}

March 1996 
SELC consists of nembers of the Department of Economies Who Work on energy and environmental economies. SEEC; $S$ aims include the pronotion of research and teaching in the broad area of energy economics and policy. SEEC was founded in 1983. Its creation was intended to consolidate the research on energy economics which developed at the University of Surrey after the appointment of Colin Robinson to the Chair of Economics in 1968. Colin and the colleagues he attracted to the University built up Surrey's reputation, initially with pioneering work on North Sea oil and gas, and subsequently in all the other major areas of energy economics.

- Recent research covers the following areas. Electricity, gas and coal privatisation in the UK, privatisation in the Middle East, the structure of UK energy demand, North Sea oil and gas economics and policy: international oil markets, electricity economics; the transport of energy, environmental policy in the UK, energy and environmental policy in the Thitd World, global environmental issues.

- SEEC research output includes SCBDS - Surrey Energy Eeonomics Discussion paper Series (recent titles nay be found on the backeover), as well as a range of other academic papers, books and monogtaphs including SEEC OCCASTONAU PAPERS

- Each year SEEC organises a tange of energy conferences and workhops on energy themes. Specialist workshops include the meetings of the the joint SEECIBIEE Energy Modelling Group convened by David Hawdon and Paul Appleby (BP)

Members of SEEC provide major inputs into the postgraduate energy courses run by the Econonies Department - in particular, the M.So. courses on Energy Economics and Energy Policy, and the Diploma in the Economies of Energy and Development for Graduates.

Enquities:

Director of SDEC and Editor of SEDDS: David Hawdon Secretary: Isobet Hildyard E.mail. D. hawdon@surrey. ac.uk E.nall.7itdward@sarrey.ac.uk

SEEC, Economies Dept, University of Surrey, Guildford GU2 $5 \times H$, UK. Telephone: +44 (0) 1483-259379 Fax: $f 44(0) 1483-303775$ 
Surrey Energy Economics Discussion paper Series

SEEDS No. 85

Freeing the Nuclear Industry

Colin Robinson

Professor of Economics, University of Surrey

This paper may not be reproduced without permission.

ISBN: $1-85237-179-\mathrm{X}$

March 1996

British Library Cataloguing-in-Publication Data.

A catalogue record for this book is available from the British Library. 


\section{ASTRACT}

In an energy market which is being liberalised, there is a good case for privatising nuclear power, moving away from the politicised decisionmaking of the past. Nuclear generators should be placed in a market in which they have to satisfy private shareholders and sell their product in competition with others. But the government's proposals have serious weaknesses. By merging Nuclear Electric and Scottish Nuclear, they suppress competition in ideas and they fail to increase rivalry in the electricity generation sector as a whole. A better devised scheme, retaining two companies but making them more equal in size (and, of course, allowing them to diversify), would have helped correct a fundamental weakness of electricity privatisation - which shows up in the ability of the major generators to set prices most of the time. 


\section{FREEING THE NUCLEAR INDUSTRY ${ }^{3}$}

\section{Introduction}

British Energy, the new company created from Nuclear Electric and Scottish Nuclear, is scheduled for privatisation in July 1996, probably by public flotation though a 'trade sale' also appears possible. ${ }^{2}$

Attention has concentrated on two aspects of the sale. One is the value of the privatised company. BZW, as adviser to the government, is reported to have placed it in the range $£ 2.4$ to 2.8 billion. ${ }^{3}$ Obviously, such valuations are subject to considerable uncertainty: estimates may change, depending on the new company's future liabilities, other terms of the sale and anticipated conditions in the electricity market.

The other issue which has attracted comment is company liabilities.

Early on, the government stated the general principle that liabilities must follow assets but turning that principle into practice has, not surprisingly,

1 This paper is an amended version of a talk given at a conference on 'Free Market Nuclear Energy 1996?', arranged by Wentworth Conference Company in association with the Major Energy Users' Council, on 6 September 1995.

2 'Minister throws nuclear sell-off into confusion', The Financial Times, 22 February 1996, and 'US utility holds talks on bid for nuclear industry', The Times, 22 February 1996.

3 'Lossmaker will move into profit after sell-off and Generating returns for nuclear investors', The Financial Times, 5 March 1996, and 'British Energy staff in line for options bonanza', The Times, 5 March 1996. 
proved contentious given the size of the financial stakes: according to newspaper reports, ${ }^{4}$ it resulted in prolonged conflict between the government and the management of British Nuclear. In February 1996, a report by the House of Commons Trade and Industry Committee ${ }^{5}$ discussed the liabilities issue at some length.

Then, in early March 1996, there were reports that most liability questions had been resolved. ${ }^{6}$ In brief, the (extremely uncertain) costs of decommissioning British energy's power stations will be met from a segregated fund to which British Energy will contribute $£ 225$ million initially and then $£ 15$ million a year for 32 years: by the end of this period, total contributions of just over $£ 700$ million will produce a sum of around $£ 4$ billion, assuming an interest rate of 3 per cent. ${ }^{7}$ Costs of reprocessing spent fuel, estimated at $£ 10.3$ billion, will be met from British Energy's revenues. The amount of debt which the new company will bear is evidently still to be settled.

4 See, for example, 'Nuclear sell-off deadlock continues', The Financial Times 29 January 1996, and 'British Energy landed with $£ 1$ bn bill', The Financial Times,2-3 March 1996.

5 Trade and Industry Committee, Second Report, Nuclear Privatisation, 14 February 1996, HC43-I and 43-II (two volumes).

6 The Financial Times, 5 March 1996, and The Times, 5 March 1996, op. cit.

7 It is not at present intended to have a similar fund for the much greater costs of decommissioning Magnox plant, which will remain state-owned. 
Fascinating though the battle between British Nuclear and the Department of Trade and Industry may be, the attention devoted to it is obscuring the purpose of nuclear privatisation. A rather negative atmosphere now surrounds that privatisation as though it were an unnecessary distraction. The disastrous post-war history of British nuclear power in the state sector is forgotten and the advantages in principle of privatising the industry - which have never been specified clearly by the government - go unrecognised.

The principal purpose of this paper is to examine the case for privatising nuclear power in Britain and to comment on the strengths and weaknesses of the scheme which the government is pursuing. ${ }^{8}$ To begin, however, it discusses nuclear privatisation in the context of recent changes in the British energy market.

\section{Energy liberalisation}

Britain's energy market has seen a remarkable transformation in recent times. In the mid-1980s, electricity, gas and coal were still nationalised and there was a 'policy' towards energy which involved a wall of

8 The government's proposals are in DTI and Scottish Office, The Prospects for Nuclear Power in the UK: Conclusions of the Government's Nuclear Review, Cm.2860, HMSO, May 1995. 
protection around British coalmining and support for British-designed nuclear power stations.

During the time of Nigel (now Lord) Lawson at the Department of Energy, the first steps were taken towards liberalising the energy market. But it took many years for change to occur. As recently as 1985, a large part of the energy market was still subject to government 'fixes'; producer interests dominated policy-making as they had done for the previous forty years; and big state-owned companies dominated the market. As monopolists they had no incentive to discover or respond to consumers' preferences. Gas privatisation was planned for 1986 but it was uncertain whether electricity would be privatised. As for coal, the idea of denationalising was so politically sensitive, it was still regarded as unthinkable. ${ }^{9}$

Eleven years on, widespread changes are under way. Gas, electricity (except for nuclear power) and coal have been privatised; the protective regime for coal has gone - indeed, there may well be some bias against coal in the new electricity market; and nuclear privatisation is promised for

9 Colin Robinson and Eileen Marshall, Can Coal Be Saved? A Radical Proposal to Reverse the Decline of a Major Industry, Hobart Paper No.105, London: Institute of Economic Affairs, 1985. 
summer 1996 along with the phased removal of existing support for nuclear power.

Because of government failure, genuine liberalisation is still some way off. Energy privatisation schemes did far too little to establish conditions which would stimulate a competitive process. As a result, the bulk of the early gains - as efficiency improved - accrued to shareholders and senior managers. Competition was not strong enough to ensure that significant benefits went to consumers.

Nevertheless, in both the electricity and gas markets these benefits have begun to appear. As the monopoly areas in both markets have been reduced, prices have fallen for those consumers with a choice of supplier. Residential consumers will also begin to benefit from 1998 onwards (earlier for those in the gas 'pilot' areas where big price reductions are being offered), despite the transitional problems there will inevitably be. Granting the power of exit to all consumers is likely to have profound effects. Once there are no longer any captive customers, supplier behaviour can be expected to change fundamentally: even if few small consumers exercise their right to change, suppliers will know that they can do so if they are dissatisfied. More innovative 'packages' of prices and 
services (including conservation services) are likely to be provided by suppliers as they strive to satisfy consumers in a rivalrous market.

\section{Nuclear privatisation and market liberalisation}

Nuclear privatisation should be seen in the light of this transformation of the energy market. It was clearly anomalous to have such a large state enclave, in the form of two nuclear companies dependent on support from the state, in a privatised industry which operates within an energy market which is being liberalised. Continuation of such a regime would have been bound to lead to tensions between state and private sectors of the industry (if, for example, there had been a serious proposal to build a large new nuclear station). ${ }^{10}$

Nevertheless, the government's decision in May 1995 to embark on privatisation of the nuclear industry caused some surprise. When the nuclear review started it was generally believed the odds were against privatisation. The logic of the arguments led quite clearly to privatising the two nuclear companies. But initially it seemed the government was wary that privatisation might again fail, as it had done in 1989 , and also that any

10 See Colin Robinson, The Power of the State: economic questions over nuclear generation, Adam Smith Institute, 1991. 
move which brought nuclear power out into public view might be a vote-loser.

\section{The market failure approach and the cases for and against nuclear power}

The alternative to privatisation was to have continued with various forms of political intervention designed either to favour or to constrain the nuclear industry.

From the mid-1950s onwards, when Britain's first civil nuclear programme was planned, governments were heavily involved in that and subsequent programmes. They supported nuclear power in various ways, but principally by inducing the nationalised electricity supply industry to build more British-designed nuclear stations than it would freely have chosen.

It was a typical piece of energy policy-making. First justified on the grounds that the resulting power would be 'too cheap to meter', it turned later into one of the means of trying to offset the effects of another government policy - coal protection, which enhanced the power of the miners to disrupt electricity supplies. 
For many years, supporters of nuclear power used a version of the 'infant industry' argument for protection; they claimed that, given government funds and time, nuclear would turn out to be the lowest-cost means of generating baseload electricity. But, by the mid-1980s, as this claim looked more and more unlikely, both they and their opponents turned to 'market failure' arguments. Markets, it was claimed, failed to take into account certain vital factors which, if brought into the reckoning, would yield an outcome different from what the market would provide. Consequently, markets could not be trusted to produce socially desirable results in the case of nuclear power."

Proponents claimed, in effect, that the presence of failures justifies 'over-investment' in nuclear power: that is, more investment should be induced - by means of subsidies, taxes on substitutes or direct controls than there would be in presently structured markets. The principal failures invoked were the supposed inability of markets to foresee and adjust to future increases in fossil fuel prices; the external environmental effects of

11 ibid. 
fossil fuel combustion, especially its alleged effect in enhancing global warming; and supply instability associated with fossil fuels. ${ }^{12}$

Opponents argued the contrary - that the relevant market failures are such that 'too much' will be invested in nuclear power if it is left to markets. Therefore, 'under-investment' is justified: penalties should be imposed on nuclear power. Generally, the case was made in terms of environmental and other externalities. It was claimed that investing in nuclear power means leaving future generations with an intractable nuclear waste problem; that there are dangers from 'routine' releases both of waste and of radiation; that stockpiles of plutonium and other material capable of being used for weapons constitute a weapons proliferation threat; and that there is an ever-present danger of accident at nuclear power stations and associated facilities.

Neither the supporters nor the opponents of nuclear power made out good cases for over-riding the market. In particular, the case made by nuclear supporters - that political action is required to deal with the 'threats' of rising fossil fuel prices, supply instability and global warming -

12 See, for example, Nuclear Electric's evidence to the Nuclear Review, especially Volume 2, The Environmental and Strategic Benefits of Nuclear Power, June 1994, and British Nuclear Industry Forum, Keeping our Energy Options Open: the case for nuclear power, July 1994. 
is deeply flawed. But, whatever one thinks of the two cases, the sharply contrasting conclusions of the two sides in the debate cast doubt on the whole market failure approach as a practical means of analysis. If, in the case of nuclear power, it can yield two diametrically opposed views of what policy should be, of what value is it?

Indeed, the nuclear debate illustrates a more general problem in analysing market failures. In practice, there is invariably so much uncertainty about what constitutes 'failures' (since all relevant failures lie in the future) and so much difficulty in quantifying them, that a very wide range of answers is bound to emerge. Thus the analysis can be used to support virtually any conceivable policy, depending on analysts' preconceptions. The field is therefore thrown open to political intervention, with all the problems thereof.

\section{Political action, government failure and markets}

Political action substitutes government failure for market failure and, because governments have a monopoly of policy-making, government failure is the more serious issue. Whenever policies have unintended consequences - as is invariably the case with human action because of our inability to see into the future, except very dimly - governments will try 
something else in an effort to remedy the problems caused by the original acts of policy. There is no obvious end to the process whereby one set of government actions has unintended consequences, which lead to more government actions designed to remedy the effects of the first set. The self-correcting tendencies of markets are absent: marketplace decisions also generate unintended consequences but the difference is that actors know they will have to bear the costs of their errors.

In energy markets, much of what is claimed to be action to correct market failures is actually action to correct the consequences of earlier government failures. The effects, though insidious, are very damaging to market processes, hampering the entrepreneurship and innovation on which, in the long run, economic prosperity depends. ${ }^{13}$

\section{Why privatise nuclear?}

For the reasons just explained, there is a strong presumption in favour of letting markets work in energy with minimal government interference. It follows, in my view, that producers of nuclear power, like producers of other energy sources, should be placed in a market in which they have to

13 Colin Robinson, Energy Policy: Errors, Illusions and Market Realities, Occasional Paper No.90, London: Institute of Economic Affairs, 1993. 
satisfy private shareholders and sell their product in competition with others. Then there will be a more genuine test of the future of nuclear power than can ever be provided by the deliberations of committees of Ministers, civil servants and industry representatives. The old regime, in which 'experts' produced levelised cost forecasts for nuclear stations resulted in disastrous decisions. It could not have been otherwise since it was the system which was at fault, not the people involved.

But what in more specific terms are the arguments for nuclear privatisation? There is both a negative case (the state sector is the wrong place for nuclear) and a positive case (the private sector is the right place). ${ }^{14}$

\subsection{The inappropriateness of state ownership of nuclear power}

The state sector is an inappropriate place for any company which makes investments with long payback periods (including power generating companies). Though politicians will offer support for a period, they have short time horizons which make them uninterested in projects which yield benefits only after many years (when another political party may be in

14 Colin Robinson, Privatising Nuclear Power: evidence for the review of future prospects for nuclear power, Surrey Energy Economics Discussion Paper No.79, Guildford: University of Surrey, 1994. 
office). The principal consequences of retaining in the state sector activities which could be private are as follows:

- large-scale long-term investments will be neglected and there will be considerable friction between public sector managements and government over such projects. Managements of public sector enterprises which, like their private sector counterparts, try to take a long-term view, are bound to clash with politicians and officials whose interest lies primarily in the short term. Moreover, the absence of useful information about costs means that debate between government and project champions is sterile. Public sector managements feel frustrated by what they perceive as poor-quality, superficial evaluations of their investment proposals.

o because of the absence of competitive pressure to set cost standards, the costs of projects which do go ahead are likely to be excessive compared with what could have been achieved in a more competitive environment. 


\subsection{An appropriate form of privatisation}

In evidence to the nuclear review, ${ }^{15}$ I suggested that nuclear power should be privatised but that the appropriate overall aim should not be nuclear privatisation per se, but privatisation of the two nuclear companies in a way which had maximum effect in stimulating competition in generation. The main features of the proposal were as follows:

- keep Magnox and associated liabilities in the state sector, but contract out their operation - perhaps by franchising for defined periods - to provide efficiency incentives.

o privatise Nuclear Electric and Scottish Nuclear not as specialist nuclear companies but as companies with generation as their main business. The companies could build nuclear, CCGT, coal or oil stations in Britain or abroad, purchase existing stations or convert existing nuclear stations to other fuels. They would be able to diversify to the extent their shareholders (and the competition authorities) allowed. They would be free to sell the electricity they produced where they could find a market. They would also be free to choose, subject to general safety rules, whether or not to

15 ibid. 
reprocess fuels, what methods of storage to use, and generally be able to manage the back-end services they require.

o make the two companies more equal in size by transferring some Nuclear Electric stations to Scottish Nuclear.

\subsection{Benefits of privatisation}

The benefits of this scheme seemed to me as follows:

- There would be significant gains in productive efficiency as the companies moved into the market for corporate control and became subject to shareholder pressure and the threat of take-over. Even though Nuclear Electric and Scottish Nuclear have improved their performance a great deal since the rest of the industry was privatised, experience with other privatised corporations suggests shareholder pressure for greater efficiency is far more powerful than any efforts by the Treasury. Government control is inherently ineffective because, in the absence of a competitive market, civil servants and politicians can have no idea what costs 'should' be.

- Efficiency gains would not be confined to the nuclear sector of electricity supply. An appropriate form of privatisation would in time greatly enhance competition in generation and in the supply of 
electricity. The greatest weakness of electricity privatisation was its failure to establish genuine rivalry in generation: the degree of rivalry is much less than it could be given the number of entrants. So many constraints have been imposed (for example, via the pooling mechanism and on fuel choice and geographical areas of operation) that competition is restricted. Nuclear privatisation could remove some of these barriers to competition - though it would take time for diversification by the 'nuclear' companies to increase competition in the pool.

- Nuclear Electric and Scottish Nuclear would become much more formidable competitors. The key to enhancing competition would lie in the diversification by the two companies away from nuclear power. Both have been severely hampered by the absurd requirement that they must generate from only one energy source in only one part of Britain. Successful companies follow where markets lead, taking up new opportunities by diversifying their activities. It is impossible to be entrepreneurial and innovative, given the confines within which the nuclear companies operate. Lifting these constraints would make them into far more powerful competitors for other generators than 
they are now, significantly increasing rivalry in generation and supply throughout the British electricity market.

- There would be better prospects of a revival of nuclear power. Though the purpose of privatising the two nuclear companies should not be to produce another nuclear power programme, at some time the climate might be propitious for building more nuclear plant. The market would then signal opportunities for companies with expertise in nuclear generation. At that time, the successors of Scottish Nuclear and Nuclear Electric would be in a strong position to build competitive new plant (the full costs of which, including back-end costs, they would bear) as compared with generating companies without recent nuclear experience. In the meantime, market processes would give both companies incentives to discover market opportunities for nuclear power and to innovate to take advantage of those opportunities.

- Efficiency gains would be passed on to consumers. The result of introducing two diversified generators (based on the two nuclear companies) to the market should be not only to increase efficiency but to pass those efficiency gains on to consumers because of increased rivalry both in generation and supply. Consumers, large 
and small, would gain from more effective competition in generation and supply, both in terms of lower prices and of contractual terms geared more closely to individual requirements. Supplies should become more secure because rivalry would produce more diversity of energy sources, generation technologies and sites.

- As well as these direct advantages to consumers, there would be a significant indirect advantage since the task of the electricity regulator would become considerably easier - and regulation to protect consumers would become more effective - if rivalry in generation was promoted by nuclear privatisation. There would be no need to supervise generation in the detail which has so far been necessary. OFFER would be able to concentrate on regulating the network of wires and ensuring the RECs do not exploit consumers in the period before competition to supply small consumers develops.

\section{The government's proposals}

The government's proposals ${ }^{16}$ differed in some crucial respects from those outlined above (and also from those which OFFER suggested). The biggest difference lies in the proposal to amalgamate Scottish Nuclear and

16 DTI and Scottish Office, Cm.2860, op. cit. 
Nuclear Electric, using a holding company structure with a headquarters in Scotland.

A good feature of the proposals is that the government was willing to grasp the nettle of nuclear privatisation. The nuclear review concluded there was no case for providing more public funds for new nuclear stations: it quite rightly dismissed the market failure and 'industrial policy' arguments for supporting nuclear power. Instead, most of the industry will be privatised.

Magnox stations and associated liabilities are to be retained in the state sector, establishing a baseload nuclear generator with a market share of about 8 per cent in England and Wales. The result should be some extra competition in generation, though it might have been better not to transfer the new company to BNFL 'in due course' as the government intends. With Magnox retained in the state sector, the way is clear for privatisation of the AGRs and the Sizewell PWR.

As most of the industry is privatised, there will be a degree of government disengagement from decision-making which is, for the reasons given earlier, very much needed given the unfortunate history of nuclear power in the state sector. The reduction of protection for nuclear power is also good news, even if the abolition of protection will be later than first 
announced. ${ }^{17}$ Consumer prices will fall as that part of the fossil fuel levy which goes to Nuclear Electric (nearly all of it) is abolished and the nuclear premium in Scotland will also disappear.

Those are the strengths of the government's proposals. But they have some very serious weaknesses. As in the cases of other energy privatisations they miss a significant opportunity (in this case, to enhance competition in electricity generation and supply). Unlike other energy privatisations they incorporate one move which may well turn out not just a lost opportunity but a retrograde step - the merger within a holding company of the two nuclear companies, under the so-called 'GBCo' option analysed by BZW, the government's advisers. I can think of no other privatisation scheme in which the government has deliberately reduced the number of companies. It is certainly a curious move for a government which claims it wishes to increase competition to generate and supply electricity.

Generally, an advantage of privatisation is that it promotes entry to the industry. As state monopoly ends, insurmountable barriers are removed

17 Instead of abolishing the nuclear portion of the levy at the time of privatisation, as the government originally intended, it appears it will be kept in place at a reduced rate until March 1998. See 'Extension of nuclear levy "breaks pledge", The Financial Times, 20 December 1995. 
and entrants appear. An initial monopolistic or duopolistic structure may therefore be of only passing consequence because actual and threatened entry will soon promote rivalry in the industry. In this case, as in others, entry barriers to the nuclear industry will be reduced when privatisation occurs. The problem is that entry to the nuclear industry is not the relevant issue because nobody, so far as I am aware, wishes to enter that industry in Britain. On the contrary, those already in the industry wish, if not to exit, to diversify away from dependence on nuclear plant.

The real problem, which nuclear privatisation could have helped to solve, is to increase rivalry in the generation sector as a whole by increased entry, especially with mid-merit plant. Such entry would lead also to increased competition to supply electricity. For various reasons, which relate to the interaction of the pooling mechanism and other features of the privatised electricity market in England and Wales, entry to generation has had little impact on the ability of National Power and PowerGen to set prices: their plant sets prices virtually all the time. ${ }^{18}$ Nuclear privatisation was a genuine opportunity to begin correcting this

18 Stephen Littlechild, 'Competition in Electricity: Retrospect and Prospect', Utility Regulation: Challenge and Response, IEA Readings No.42, London: Institute of Economic Affairs, 1995; and Memorandum submitted by Colin Robinson, in Trade and Industry Committee Report, Aspects of the Electricity Supply Industry, HC481 II, London: HMSO, 1995. 
fundamental weakness of the privatisation scheme, bringing more competition to both the pool and the contract markets.

But the government's scheme does not address this crucial issue. Instead of privatising the two nuclear companies as separate units though equalised in size, it intends to merge them. Under the scheme I suggested and the one put forward by OFFER, ${ }^{19}$ two formidable new competitors to National Power and PowerGen would have appeared: they would have been rather like new entrants because they would have been freed from the constraints which up to now have hampered them. Real rivalry in the generation market would probably have been the consequence, even if it took a little time to emerge.

Instead, the merged company, though in the private sector and without the protection which the nuclear companies have had up to now, looks suspiciously like a strengthened version of the third leg of the existing 'triopoly' which has been so criticised by OFFER. ${ }^{20}$ All the Nuclear Review White Paper feels able to claim is that the scheme '...would increase competition in the electricity market through the

19. Office of Electricity Regulation, Submission to the Nuclear Review, October 1994. See also David Newberry, Memorandum in $\mathrm{HC} 43-\mathrm{H}$, op. cit., pp.49-51.

20 ibid. 
separating out of the Magnox stations to form a new generating force...' (para. 7.23). ${ }^{21}$

Moreover, the government has lost the opportunity to cultivate competition in ideas which is so important in stimulating entrepreneurship and innovation. The two nuclear companies have shown, even under state ownership, that they had diverse ideas (as, for example, in Scottish Nuclear's development of dry storage). That diversity will, under the government's scheme, be suppressed. For forty years, Britain suffered the consequences of having an information monopoly in nuclear power: all the information on costs and available technologies came from one source with a vested interest in nuclear expansion so it is hardly surprising that cost estimates were over-optimistic. The privatisation scheme is not simply a reversion to those days. But, in an industry which has obviously suffered in the past from the absence of a diversity of ideas, to suppress such diversity as presently exists seems a most peculiar action.

Presumably, the reasoning behind the scheme is primarily political calculation. That is only to be expected, since it is an action by government. As in other privatisations, the government's top priority is evidently not to inject competition but to raise as large revenues as it

21 The Prospects for Nuclear Power in the UK, op. cit. 
reasonably can in the near term. ${ }^{22}$ It believes it will be able to do so more easily by the merger than if it sold two competing companies. It also expects to be able to accomplish the privatisation more quickly by floating the merged company: obviously, at present it must have its eye on a General Election no more than a year away.

Other arguments used to support the proposal by the government and some parts of the nuclear industry - that it will maintain safety, exploit economies of scale, strengthen research and development and establish a British 'national champion' in nuclear power - seem entirely spurious. In none of these respects is there any reason to believe one company is better than two.

One can see the short-run appeal of the government's approach and politicians can hardly be blamed for making calculations based primarily on political factors. But even in terms of the political calculus, the scheme is misguided since it repeats the errors of earlier privatisations. Now the consequences of those privatisations are so obvious, it is surprising the government is not more concerned with competition-promotion. After all, one of its biggest headaches recently has been public disquiet about the

22 Colin Robinson, 'Deregulating the British Energy Industries: The Lessons to be Learned', Metroeconomica, 1-2, 1992. 
privatised utilities, which springs essentially from privatisation schemes which injected inadequate competition and so brought few benefits to consumers in the early years.

Both in gas and electricity, though privatisation was necessary to permit entry to the market, the schemes were not nearly sufficient to bring in entrants able significantly to reduce the market power of the incumbents. Most of the credit for injecting competition goes to the regulators. In the gas industry, where British Gas was established as a monopoly, successive regulators have struggled for almost ten years to bring some gains to consumers. In electricity, where again there was little competition, the regulator has had an immensely difficult task in trying to bring some rivalry into an industry with such a poorly conceived privatisation scheme. That is why privatisation and the regulators are unpopular. It is not privatisation per se but the way it was done and the consequences for regulation which are the problems. ${ }^{23}$

And yet, despite these examples, the government is again embarking on a scheme which fails to seize the opportunity to promote entry to an industry and to stimulate genuine rivalry. These opportunities, once

23 Colin Robinson, 'Profit, Discovery and the Role of Entry: Applications in Electricity', in M.E. Beesley (ed.), Utility Regulation, IEA (forthcoming) 1996. 
passed, cannot be recaptured: an industry cannot be privatised again. Once privatisation has occurred, incumbents which have been left with market power will always claim that the settlement with government at the time of privatisation had sanctity. Consequently, it takes many years - during which regulators struggle with incumbents - for consumers to receive benefits they could have had from the beginnings of the privatised market.

So nuclear privatisation can be given only a qualified welcome. Privatising nuclear power is a good idea, as is reducing protection for the industry. But the scheme itself seems ill-considered. It fails to enhance competition in the generation sector generally and it suppresses competition in ideas in the nuclear sector. The merger of Nuclear Electric and Scottish Nuclear is a retrograde step.

Nuclear privatisation has not happened yet so the government is not absolutely committed to a single nuclear company. Changes are not unusual as the day of flotation approaches. No doubt this time it seems too late to retract. But it would be better to do so. The government should ponder the alternatives more carefully and place more emphasis on the interests of energy consumers. Otherwise, the result will be yet another energy privatisation which leads to severe problems as a regulator tries to correct for the deficiencies of the privatisation scheme. 




\section{SURREY FNERGY HCONOMICS DISCUSSION PAPER SERIES (SEEDS) and SEEC OCCASTONAL PAPERS \\ SEEDS Number}

85. Ereeing the Nuclear Industry

Colin Robinson

ISBN $185237179 \mathrm{X}$ : March 1996

84. The Efficiency of the National Electricity Board in Malaysia

- an Intercountry Comparison $\quad$ ISBN $185237165 \mathrm{X}$. January 1996

Jamaluddin bin Mohd Yunos and David Hawdon

83 Privatisation: Saving the British Coal Industry?

Colin Robinson

ISBN 1852371633 . November 1995

82 Electricity Privatisation in England and Wales: Progress and Problems Colin Robinson

ISBN 1852371528

August 1995

SEEC OCCASIONAL PAPER

No.2 The S. E.E. C. United Kingdom Energy Demand Forecast 1995 2000) Update

Roger Fouquet, David Hawdon, Peter J G Pearson, Colin Robinson and Paul Stevens ISBN $185237151 \mathrm{X}$

July 1995

81. The Nuclear Review

David Hawdon (Ed): Elroy Dimson, Robin Jeffrey, Martin ONeil M.P, Colin Robinson and Mike Staunton ISBN 1852371501 April 1995

80 Regulation as a Means of Introducing Competition

Colin Robinson ISBN $185237148 \times$ February 1995

79. Privatising Nuelear Rower: evidence for the review of future prospects for nuclear power

Colin Robinson

ISBN 1852371455 Novenber 1994

78 Energy, Externalities and Environmental Quality: Will Development

Cure the Ills it Creates?

Peter J.G. Pearson

ISBN 1852371447 . October 1994

77. The Demand for Car Fuel Efficiency: An Hedonic Price Approach

Robert Witt ISBN 1852371439

October 1994

76 Economics and the Environment- The Shadow Price of

Greenhouse Gases and A erosols

David Maddison

ISBN 1852371412

July 1994

see over $>>>$ 


\section{SURREY ENERGY ECONOMICS DISCUSSION PAPER SERIES (SEEDS) and SEEC OCCASIONAL PAPERS (contd)}

SEEDS Number

75 End Use Elasticities

Joseph G Hirschberg

ISBN 1852371404 June 1994

74 A Model of Relative Price Elasticities from the Second

Noments of Demand

Joseph G Hirsehberg

ISBN 1852371390

June 1994

73 . Liberalisation of the Energy Market A Favounable

Supply-side shodk for the UIF Economy

Colin Robinson

ISBN 1852371382

June 1994

SEEC OCCASTONIL PAPER

No.1. The Future of UK Energy Demand-The S.E. E. C. United Ringdom Eneravi:

Demand Eorecast (1993-2000)

Roger Fouquet, David Hawdon, Perer I G Pearson, Colin Robinson

and Paul Stevens

ISBN 185237134X 16 Decenber 1993

12 Recentstudies of the Demand tor Enetgy in the TuK

D Hawdon (Ed) Joyce Dargay, Roger Fouquet Andrew Henley. Keith Miller and John Peirbon W ISBN 1852371331 Novernber 1993

71 An Econometric Study of the Demand for Gasoline in the Gulf

Cooperation Counchl Countries ISBN 1852371315. October 1993. M Nagy Etrony \& Nohamnad Nlmahmeed

International Batgaining and the EC Large Conbustion Plant Directive Roger $\mathbf{R}$ ouquet

ISBNI 1852371129

Iuly 1993

69. Fuels for Electricity Sumply after the UR Coal Reviev. Peter 1 G Pearson (Ed): Anthony Baker, Nigel Evan, P MS lones and Colin Robinson

ISBN 18523710099

Nay 1993

68 Blectricity in the Third World

Peter I G Pearson (Ed). Andrew Bamet, Gerald Foley, Francis VraGonan and Peter I G Pearson

ISBN 1852371080

Nay 1993

67 The Economics of Pit Closures in the UK

Peter J G Pearson (Ed) 3 papers by Anthony Baker et al

ISBN 1852371064

January 1993

Details of SEEDS 1-66, prices and annual Subscription Schente on tequest 